UDC 632.4: 635.9

\title{
PARASITISM OF MICROMYCETE SCLEROTINIA SCLEROTIORUM (LIB.) DE BARY ON THE DAHLIA PLANTS (DAHLIA CAV.) UNDER DIFFERENT WEATHER CONDITIONS
}

\author{
M.Y. PIKOVSKYI, PhD of Biology Sciences, docent of the department of phytopathology \\ https://orcid.org/0000-0003-0689-604X \\ E-mail:mprmir@ukr.net \\ O. V. KOLESNICHENKO, Doctor of Biological Sciences, Professor of Department of \\ Decorative Gardening and Phytodesign \\ https://orcid.org/0000-0003-4767-6844 \\ E-mail: okolesnichenko67@gmail.com \\ V. I. MELNYK, PhD of Agricultural Sciences, Associate Professor \\ https://orcid.org/0000-0002-8782-1236 \\ E-mail:vik4865@ukr.net \\ O. O. SEREDIUK, PhD of Agricultural Sciences \\ National University of Life and Environmental Sciences of Ukraine
}

https://doi.org/ 10.31548/bio2019.03.002

The white mold of dahlia is a dangerous disease that remains unexplored in Ukraine. In order to study the symptoms of the disease and the impact of meteorological conditions on its development, a study was conducted in 2015-2017 in Kyiv. In studying the diagnostic signs of the disease, a visual examination, and a biological method of diagnosis were used. The development of the disease was estimated at a six-point scale. As a result of phytopathological monitoring, the stalk form of white mold was found. Substantial damage to plants resulted in tissue maceration and fragmentation of stems and peduncles. The development of the disease of the stem led to plant wilting. During the years of research, white mold on dahlia manifested itself in the autumnal period of plant growth during mass flowering. Meteorological conditions have significantly influenced its distribution and development. In particular, in 2015, Sclerotinia white mold of dahlia manifested itself from the first decade of September for a hydrothermal coefficient (HTC) of 1.0. In 2016, the disease appeared on plants in the first decade of October, when the HTC was 5.7. The first plants affected by white mold in 2017 were marked by the second decade of September for the HTC 1,2. It was that year when the disease has reached the maximum spread and development, which is due to the presence of precipitation from the second decade of September and until the end of October, as well as the absence of low temperatures during this period. Information about the dates of the appearance of the white mold on the dahlia deserves attention when planning a set of protective measures. In prospect in depth analysis of the influence of various meteorological factors on the development of white mold on dahlia should be used in drawing up models of the prediction of disease development in this culture.

Keywords: white mold, dahlia, symptoms, meteorological conditions, development of the disease 
Introduction. Dahlia (Dahlia Cav.) is one of the most popular perennial herbaceous flowering plants, which is characterized by distinctive, attractive flowers of various shades and colors and is grown in many regions of the world (Verma J., Kulkarni S. B., 2017).

At the same time, as a result of the damage to plants by various pathogens (Botrytis cinerea, Verticillium spp., Entyloma calendulae f. dahliae, Phytophthora spp., some viruses), the duration of their flowering, decline or loss of decorative character, decrease of the stability of tubers against diseases during storage (Sharma K., Verma Sh., Gautam, H.R., Handa A., 2017). In different countries, powdery mildew occurs in dahlias (Dai, Y.-F. et al., 2018), viral diseases (Almeyda, C. V. et al., 2009). On dahlia plants Choanephora cucurbitarum micromissette parasites were found (Park, J. H. et al., 2016). At the same time, one of the most dangerous dwarf diseases is white mold caused by the micromycete Sclerotinia sclerotiorum (Lib.) de Bary (Horst R.K., 2008). However, in Ukraine, it has not been studied. Thus, there is no information on the symptoms of dahlia Sclerotinia white mold and the characteristics of the disease in different meteorological conditions. At the same time, S. sclerotiorum is a common pathogen in agrocenoses of open soil and in greenhouses on many cultures (Kyryk, M. M., Pikovskyi, M.Y., Azaiki, S., 2012; Willbur, J.F. et al., 2018).

Anallysis of the lasts researches and publication. In scientific literature, the information on the parasitism of S. sclerotiorum on the dahlia is fragmentary. In particular, (Kerruish, R. M.,1997) indicates the development of a stemlike form of Sclerotinia white mold, which led to plant wilting. Horst R.K. (Horst R.K., 2008) also emphasizes the mold of the stalk of the dahlia. In the classical literary sources relating to the diseases of flowering plants, the white mold of dahlia is undetectable.

The aim of research. Purpose of the investigation is the study of dahlia white mold symptomatics and the disease development peculiarities depending on the weathers conditions.
Materials and methods of the exploration. The studies of the $S$. sclerotiorum development peculiarities on the dahlia perennial plants were carried out during the route inspections in the vegetation period of 20152017 at the Kyiv Territorial Centre of the National University of Life and Environmental Sciences (NULES) of Ukraine on the natural infections background. The specification of the disease symptoms and pathogen morphological study were conducted in the Experimental Laboratory «Mycology and Phytopathology» with the use of the accept methods (Böttcher, I. et al., 1987).

Stationary plots were selected in the dahlia plantings. Estimates were carried out on the plants there every decade. The disease spread was expressed by the formula:

$$
P=\frac{n \times 100}{N},
$$

Where $P$ - is appearance frequency, \%;

$n$-samples amount in which these species were detected;

$N$ - total number of the researched;

The affection intensity was determined utilizing the scale which we had developed: 0 - the disease symptoms were absent; 0,1 - the affectioned part on the stem was up to $10 \mathrm{~mm}$ long. The diseased tissue resembled wet or dry decolourized tissue; 1 - the space of the stem affectioned part was $10-20 \mathrm{~mm}$; it was covered with white cotton wool-like mycelium, that under the dry conditions was expressed weakly and the diseased tissue was decolourized; $1 / 2$ of the stem circumference was enveloped with disease; 2 - the affectioned part of the stem was $20-40 \mathrm{~mm}$ long; under the humid conditions the place of the affection was covered with white cotton wool-like mycelium on which the pathogene sclerotia were formed; in the dry weather the disease places were decolourized, sclerotia single since when getting dry they fell on the soil surface; the entire circumference was envylopped with the affectioned tissue; the disease symptoms were also 
on the lateral shoots; 3 - the length of the stem affectioned part was 30-50 \%, the affectioned tissure was covered by white mycelium and sclerotia or can be decolourized with the weakly developed mycelium; the disease causative agent sclerotia appear in the middle of the stems; separate lateral shoots dried, were cracked; the part above the affection place began to wither; 4 - the stem was affected almost in full; the disease symptoms were observed as well on the lateral shoots, among them floriferous ones; the affectioned tissure of the stem and shoots got soaked, that caused their cracking and the plant perished.

The white mold development was determined applying the formula:

$$
R x=\frac{\sum(a \times b) \times 100}{N \times K},
$$

where $R_{x}$ - the disease development, \%; $\sum(\alpha \times b) \times 100-$ is product of the diseased plants amount for the corresponding point of affection;

$N$ - is total number of the estimated plants (healthy ad diseased);

$K$ - is the highest point of the estimation scale.

The hydrothermal coefficient (HTC) by the methods of G.T. Selyaninov was determined using the formula:

$\mathrm{HTC}=\Sigma \mathrm{x} / \Sigma \mathrm{tx} 10$,

where $\Sigma \mathrm{x}$ and $\Sigma \mathrm{t}$-accordingly sum of precipitations and temperatures in the period, when the temperature has not been lower than $10^{\circ} \mathrm{C}$.

Results of the researches and their discussion. The stem form of the storage rot display was noted is cases of the dahlia plants affection by the fungus $S$. sclerotiorum. This form can appear both at the basis (near the soil surface) and in any it's part. At the beginning of the disease development wet, saturated, with moisture spots appeared on the stems. Their site increased and under the high air humidity those spots were covered with white cotton wool-like mycelium which in some time thickened (fig. 1a) and transformed into black sclerotia (fig. 1b). When affectioned tissues got dry they fell on the soil surface. Sclerotia could also be detected in the middle of the infected stems and floriferous shoots (fig. 1c).

Under the disease intensive development, the affectioned part of the stem achieved considerable size (the infection spread upwards and downwards from the affection place). In our investigations the storage root also displayed on the floriferous shoots and peduncles of leaves. The strong plants affection appeared to cause the tissues maceration that brought about the cracking (fig. 2a) of stems and floriferous shoots (fig. $2 b)$. The disease displays in the stem radical part caused the plants withering. As a result, buds and flowers got dry (fig. 2c).

The decolorizing of the parts affectioned by $S$. sclerotiorum was noted as well. As a rule, this took place after the periods of the plants moistening and infection - the weather conditions became more droughty. At the same time the mycelium and sclerotia continued to form in the middle of the affectioned stems.

As some authors state the storage rot, spread is influenced by the weather factors and other conditions which cause the plants affection by the pathogene at certain their growth and development stages [9]. At the same time those problems concerning dahlia are not studied. That demands these aspects making sure as for this crop.

The analysis of the dahlia plants vegetation period weather conditions in the summer months of 2015 showed that in June the average daily temperature was 20,7;20,6 and $18,7^{\circ} \mathrm{C}$ respectively depending on a decade (fig. 3). The precipitations amount was 4,0 $\mathrm{mm}$ during the entire month. The plants affection monitoring by the storage rot defected the disease absence. During July the average daily temperature was $21,6{ }^{\circ} \mathrm{C}$ the beginning and middle of the month being characterized with the precipitations deficit 


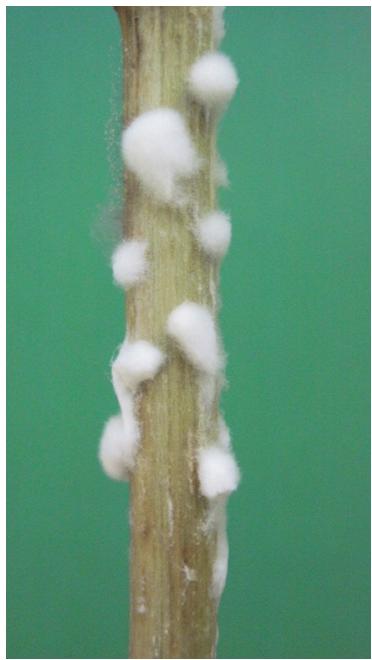

a

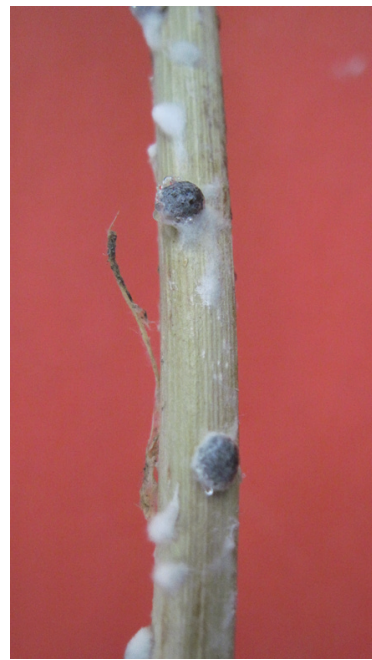

b

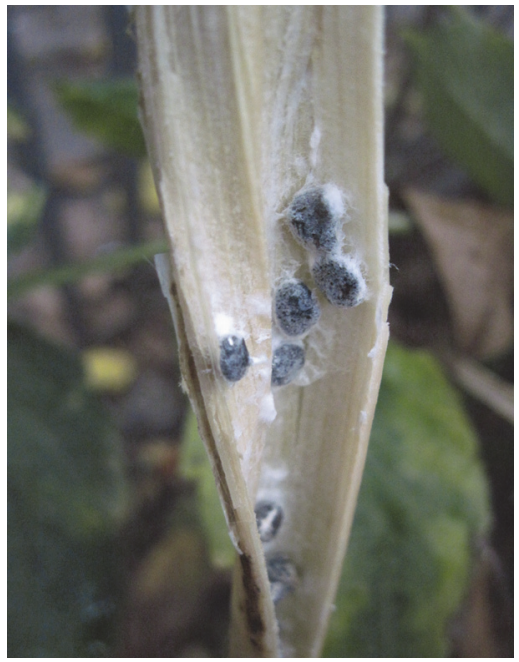

C

Fig. 1. Diagnostic symptoms of the dahlia stem affection by S. sclerotiorum: (a) the pathogen mycelium on the infected tissues surface; sclerotia on the affected part surface (b) and in the middle of the stem (c)

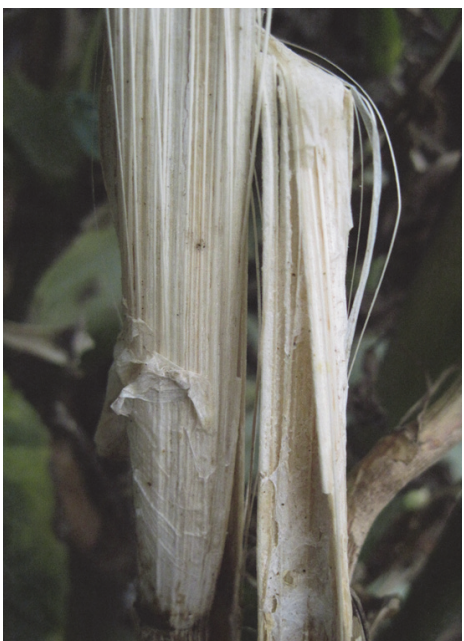

a

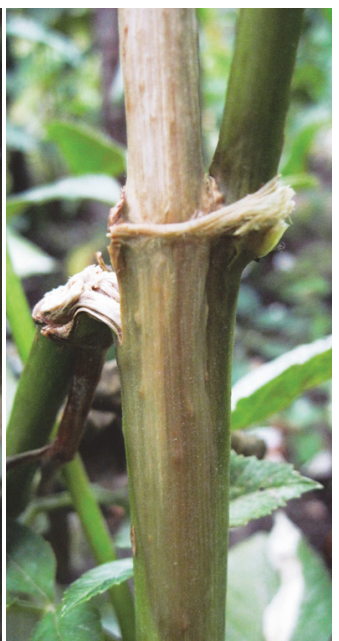

b

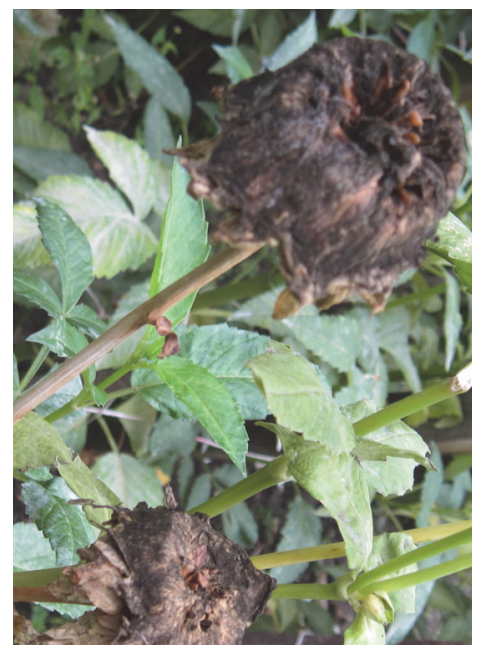

C

Fig. 2 Cracking of the dahlia stem (a) and floriferous shoot (b) affected by the white mold; flowers drying as a result of the disease stem form display (c)

and in the third decade their number was $33,2 \mathrm{~mm}$. During the mentioned period the plants affection by $S$. sclerotiorum was not detected either. The weather conditions in August were characterized with average daily temperature 22,$8 ; 21,4$ and $20,3{ }^{\circ} \mathrm{C}$ respec- tively depending on the decades. The precipitations amount was insufficient $(5,8 \mathrm{~mm}$ during the first and second decades). The analysis of the plants phytopathological state showed the storage rot absence. September was characterized with the gradual average 
daily temperature lowering from 18,3 to 17,1 and $16,7^{\circ} \mathrm{C}$, during the first decade the precipitations number was $18,8 \mathrm{~mm}$, HTC being 1,0 . The first plants with the storage rot stem form symptoms were detected just in the first decade of September, the disease spread being 5,0 \% and its development 2,5\%. Afterwards the affected plants amount did not increase in the first and second decades. The dahlia plants vegetation lasted in October. During this period the average daily temperature in the first, second and third decades was 14,0; 3,0 and 4,6 respectively, the precipitations number $33,6 \mathrm{~mm}$, the disease spread being $5,0 \%$, its development $4,5 \%$.

When growing and developing of the dahlia plants in the June of 2016 the average daily temperature ranged from $16,7-24.6^{\circ} \mathrm{C}$ the precipitations sum was $21,5 \mathrm{~mm}$ (fig. 4), in July 19,$9 ; 23,6 ; 22,3{ }^{\circ} \mathrm{C}$ and $42 \mathrm{~mm}$ respec- tively (depending on a decade), in August 20,2 ${ }^{\circ} \mathrm{C}$ and $26,8 \mathrm{~mm}$. During the summer vegetation period the storage rot dahlia was not detected. In September the average daily temperature was 18,$2 ; 15,3$ and $10,9{ }^{\circ} \mathrm{C}$ (depending on a decade), the precipitations amount $6,8 \mathrm{~mm}$. Under such conditions the storage rot on dahlia was not observed. The average daily temperature in the first decade was $10,7^{\circ} \mathrm{C}$, precipitations number $63,6 \mathrm{~mm}$. Just then the first plants affected by the storage rot were detected (2,5\%). By the end of the vegetation period their amount was 5,0 $\%$ under the disease development $1,9 \%$.

The weather conditions of the dahlia plants vegetation in the June of 2017 were characterized by the average daily air temperature $18,5-21,6^{\circ} \mathrm{C}$, the precipitations sum being $16,4 \mathrm{~mm}$ (fig. 5), in July 19,$9 ; 23,0 ; 22,3^{\circ} \mathrm{C}$ and $42 \mathrm{~mm}$ respectively. The average daily air tem-

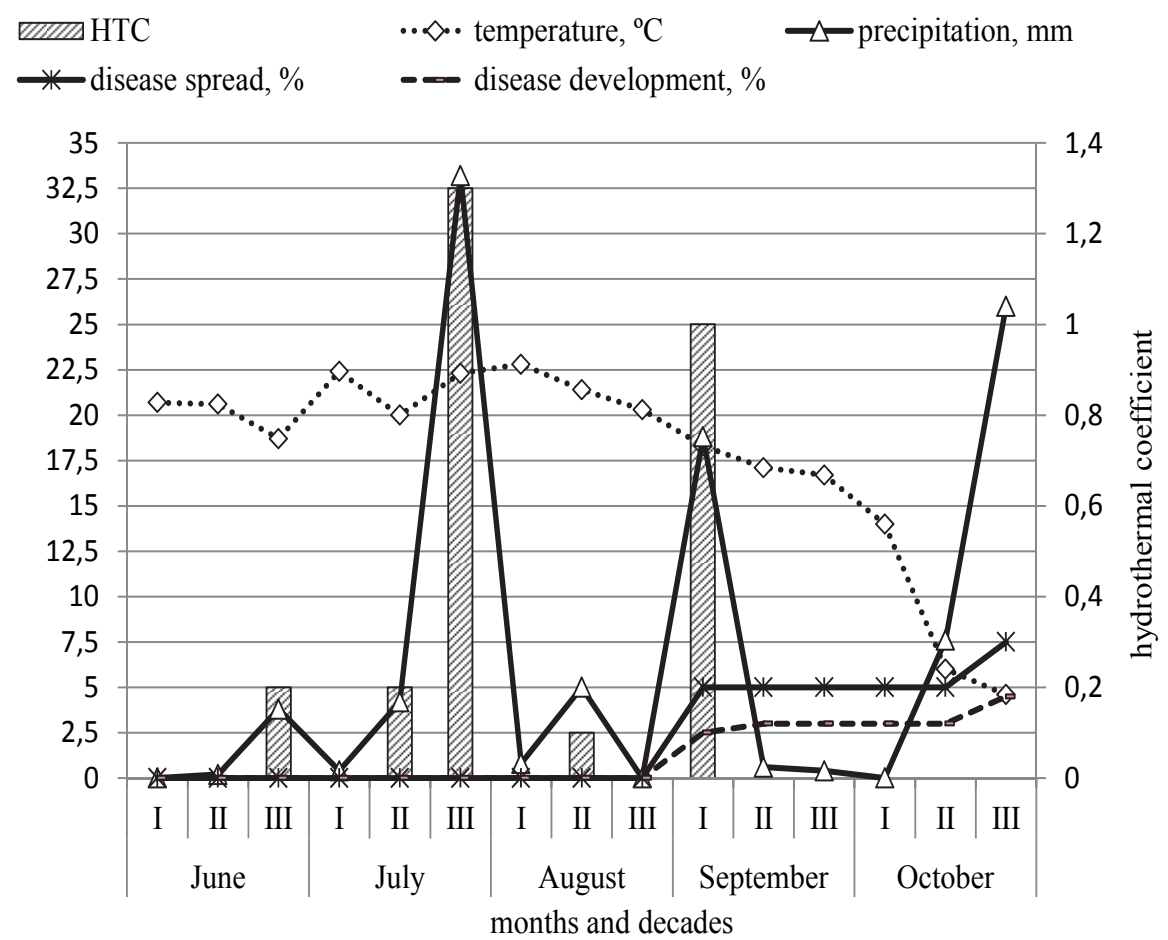

Fig. 3. Dynamics of the dahlia white mold development (2015) 


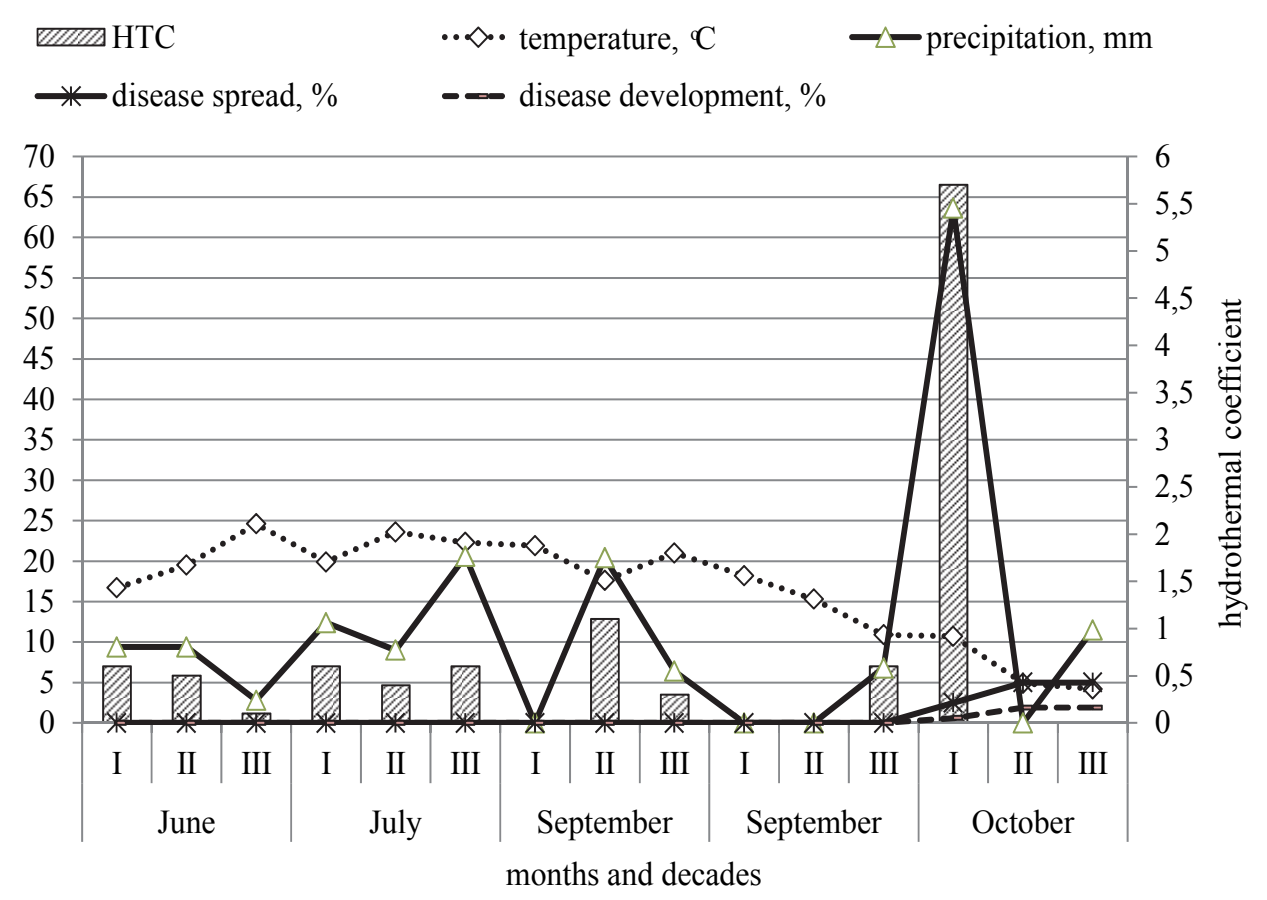

Fig. 4. Dynamics of the dahlia white mold development (2016)

perature at the beginning and in the middle of August was high: in the first decade $29,8^{\circ} \mathrm{C}$, in the second one $30,1^{\circ} \mathrm{C}$. In the third decade this index was at a level of $21,4^{\circ} \mathrm{C}$. The precipitations amount in August was 41,4 mm. The phytopathological analysis of the dahlia plants in the summer months did not detect the affection by the storage rot causative agent. The first decade of September distinguished itself for the average daily air temperature decrease to $16,6^{\circ} \mathrm{C}$ and its increase to $18,9^{\circ} \mathrm{C}$ in the second decade. From now on at the end of September this indicator was $14,5^{\circ} \mathrm{C}$. The greatest precipitation number in this month was noted in the second decade $-22,4 \mathrm{~mm}$ and in general their monthly sum achieved $26 \mathrm{~mm}$. The dahlia plants monitoring in September showed their affection by the storage rot in the second decade, the disease spread being 7,5 $\%$, its development $1,9 \%$. Later on the disease spread. In October the dahlia plants vegetation continued. The average daily air tempera- ture (the first decade $10,7^{\circ} \mathrm{C}$, the second one $11,3^{\circ} \mathrm{C}$ ) contributed to this. At the end of the month in lowered to $5,9^{\circ} \mathrm{C}$. The precipitations amount in October was $93 \mathrm{~mm}$ (the first decade $62,2 \mathrm{~mm})$. The maximum disease spread $(12 \%)$ and plants affection intensity $(6,9 \%)$ were noted.

The integral indicator - hydrothermal coefficient - was analyzed for the determination of the simultaneous effect of the temperature and precipitations on the terms of the dahlia white mold appearance. For instance, in 2015 the dahlia appeared, beginning since the first decade of September, under HTC 1,0. In 2016 the disease was observed on the plants in the first decade of October when HTC was 5,7. In 2017 in the second decade of September (HTC 1,2) respectively. In all the cases the storage rot appeared in the autumn vegetation period when the plants flowering in mass. The disease acquired maximum spread and develop- 


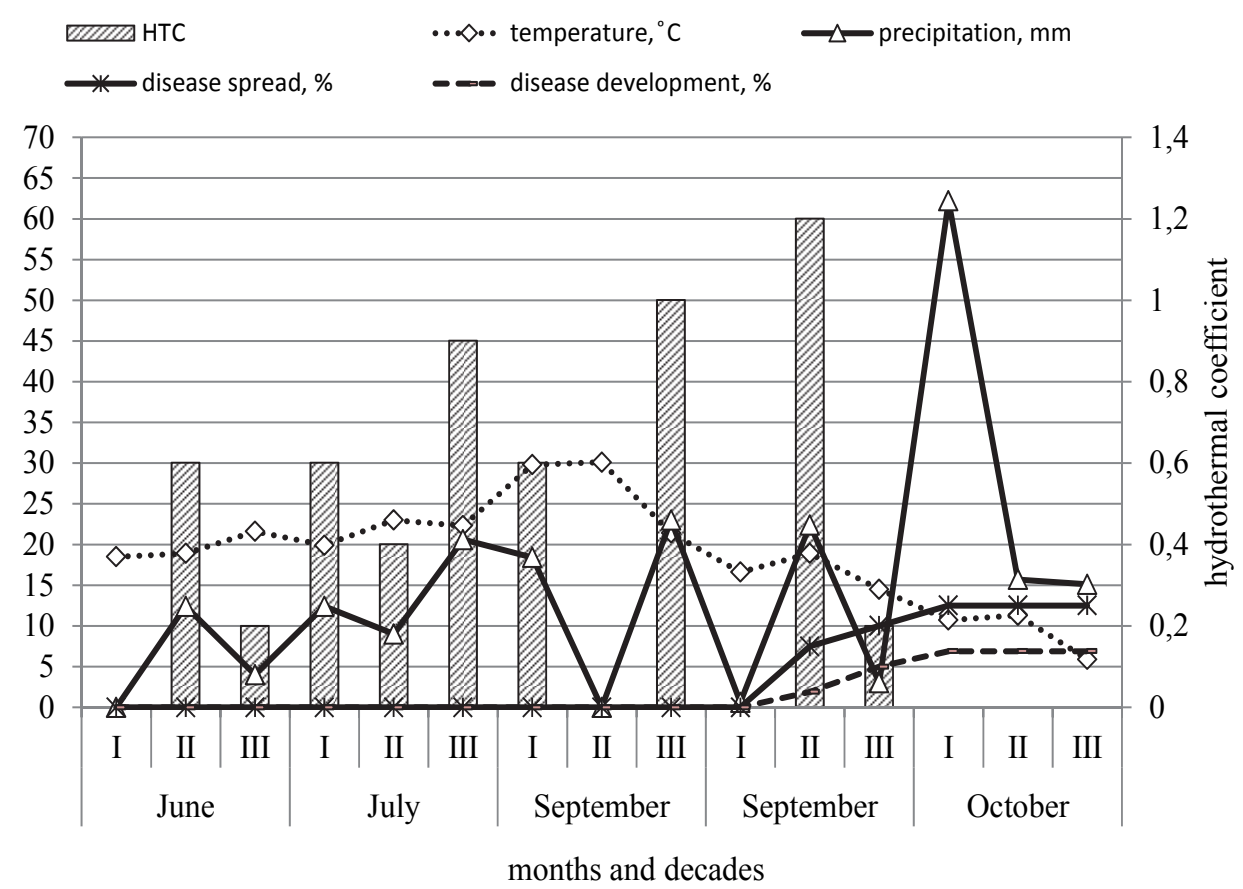

Fig. 5. Dynamics of the dahlia white mold development (2017)

ment in 2017. In our opinion, it was conditioned by precipitations beginning from the second decade of September to the end of October and by the low temperatures absence in this period. It should be noted that even under the inconsiderable disease development degree the pathogen colonizing stems caused their doing off. The bulbs were infected in case of the affection of plants down parts by $S$. sclerotiorum.

\section{Conclusions and promises}

1. The white mold form was detected as result of the dahlia plants monitoring. The strong plants affection brought about the tissues maceration that caused cracking of stems and floriferous shoots. The disease displays in the stem down part brought about the plants withering. As a result, buds and flowers dried.

2. In the research years (2015-2017) the storage rot appeared on dahlia in the autumn plants vegetation period during their mass flowering. The disease spread and develop- ment were influenced by the weather conditions. In particular, in 2015 the dahlia Sclerotinia symptoms were displayed beginning from the first decade of September under HTC 1,0, in 2016 in the first decade of October and 5,7 respectively, in 2017 in the second decade of September and 1,2 respectively. Just in 2017 the disease acquired maximum spread and development. That, in our opinion, was conditioned by the precipitations beginning from the second decade of September to the end of October and low temperatures absence in this period.

3 . If there is information about the terms of the storage rot appearance on dahlia it should plan a number of measures concerning its control. Generally, in the future the results of the analysis of the different weather factors effect on the dahlia storage rot development is expedient to apply for composing models of the disease development prediction on this crop. 


\section{References}

1. Böttcher, I., Wetzel, T., Dreve, F.V., Kegler, X., Naumann, K., Freier, B., Frauenstein, K., Fuchs, E. (1987). Metody opredeleniya bolezney i vrediteley sel'skokhozyaystvennykh rasteniy [Methods for determining diseases and pests of agricultural plants] Trans. with him. K.V. Popkova, V.A. Shmygli, Moscow, Agropromizdat, 224. (in Russian).

2. Almeyda, C. V., Raikhy, G., Pappu, H. R. (2015). Characterization and comparative analysis of promoters from three plant pararetroviruses associated with Dahlia (Dahlia variabilis). Virus genes. 51 (1). 96-104. doi: 10.1007/s11262-015-1196-7

3. Dai, Y.-F., Xiang, L.-G., Wang, H.-C., Chen, X.-J., Chen, X., Yang, X.-H. (2018). Powdery Mildew of Dahlia pinnata Caused by Golovinomyces cichoracearum in Guizhou Province of China. Plant Disease. 102 (12). 2654. https:/ / doi.org/10.1094/PDIS-04-18-0649-PDN

4. Horst R.K. (2008). Westcott's Plant Disease Handbook. Springer-Verlag, Berlin Heidelbert, New York. 1343.

5. Jyoti Verma, Balaji S. Kulkarni (2017). Evaluation of Dahlia Genotypes for Growth and Yield Characters under Dry Zone of Karnataka. Int. J. Curr. Microbiol. App. Sci. 6 (11). 402-409. doi: https://doi.org/10.20546/ijcmas.2017.611.046

6. Kerruish, R. M. (1997). Plant protection 3. Selected Ornamentals, Fruit and Vegetables. RootRot Press. 700.

7. Kishor Sharma, Shalini Verma, Gautam, H.R., Anil Handa. (2017). First Report of Powdery Mildew Caused by Golovinomyces cichoracearum Dahlia (Dahlia variabilis) from Himachal Pradesh (India). Int.J. Curr. Microbiol.App.Sci. 6 (6). 1595-1598. doi:https:/ / doi.org/10.20546/ijcmas.2017.606.187

8. Kyryk, M. M., Pikovskyi, M.Y., Azaiki, S. (2012). Diagnostic signs of diseases of vegetable crops and potato. Kyiv. Phoenix. 175.

9. Park, J. H., Choi, I. Y., Park, M. J., Han, K. S., Shin, H. D. (2016). First Report of Choanephora Flower Blight on Dahlia pinnata Caused by Choanephora cucurbitarum in Korea. Plant Disease. 100 (2). 534. https:/ / doi.org/10.1094/PDIS-08-15-0936-PDN

10. Sahar, E., Keri, L. D., Dayle, E. S., Hanu, R. P. (2009). Incidence of multiple and Distinct Species of Caulimoviruses in Dahlia (Dahlia variabilis). Hortscience, 44 (5). 1498-1500. https://doi. org/10.21273/HORTSCI.44.5.1498

11. Willbur, J.F., Fall, M.L., Bloomingdale, C., Byrne, A.M., Chapman, S.A., Isard, S.A., Magarey, R.D., McCaghey, M.M., Mueller, B.D., Russo, J.M., Schlegel, J., Chilvers, M.I., Mueller, D.S., Kabbage, M., Smith, D.L. (2018). Weather-based models for assessing the risk of Sclerotinia sclerotiorum apothecial presence in soybean (Glycine max) fields. Plant disease, 102 (1). https://doi. org/10.1094/PDIS-04-17-0504-RE

\section{АНОТАЦІЯ}

М. Й. Піковський, О. В. Колесніменко, В. І. Мельник, О.О. Середюк. Паразитування мікромічета sclerotinia sclerotiomum (lib.) De bary на рослинах жоржини (dahlia cav.) За різних метеорологічних умов. Біоресурси і природокористування. 2019. 11, №3-4. C.16-24. https://doi.org/ 10.31548/bio2019.03.002

Анотахія. Біла гниль жоржини є небезпечною хворобою, яка в Україні залишається мало дослідженою. Для вивчення симптоматики хвороби та впливу метеорологічних умов на ї̈ розвиток нами проведено дослідження протягом 2015 - 2017 рр. на територї м. Кисва. Під час вивчення симптоматики захворювання застосовували візуальний огляд $i$ біологічний метод діагности ки. Розвиток хвороби оцінювали за шестибальною шкалою. У результаті фітопатологічного моніторингу виявлено стеблову форму білої гнилі. Сильне ураження рослин призводило до мачерахї тканин $i$ надламування стебел $i$ квітконосів.
Розвиток хвороби у прикореневій частині стебла призводив до в'янення рослин. За роки досліджень біла гниль на жоржині проявлялася в осінній період вегетаиї рослин під иас масового ивітіння. На ї̈ поширення та розвиток значно впливали метеорологічні умови. Зокрема, у 2015 роиі склеротиніоз жоржини проявлявся починаючи 3 першої декади вересня за гідротермічного коефіиієнта (ГТК) 1,0. У 2016 рочі хвороба з'явилася на рослинах у першій декаді жовтня, коли ГТК становив 5,7. Перші рослини, уражені білою гниллю у 2017 р. нами відмічені у другій декаді вересня за ГТК 1,2. Саме у иъому рочі хвороба 
набула максимального поширення та розвитку, шо зумовлено наявністю атмосферних опадів починаючи з другої декади вересня та до кіния жовтня, а також відсутністю низъких температур за ией період. Інформачіл шодо строків з'явлення білої гнилі на жоржині заслуговує на увагу під час планування комплексу захисних заходів.
У подальшому глибокий аналіз впливу різних метеорологічних факторів на розвиток білоӥ гнилі жоржини дочільно застосовувати при складанні моделей прогнозу розвитку хвороби на uій культурі.

Ключові слова: біла гниль, жоржина, симптоми, метеорологічні умови, розвиток хвороби

\section{АННОТАЦИЯ}

М. И. Пиковский, Е. В. Колесниченко, В. И. Мельник, А. А. Середюк. Паразитирование микромичета sclerotinia sclerotiorum (lib.) De bary на растениях георгины (dahlia cav.) При различных метеорологических условиях. Биоресурсы и природопользование. 2019. 11, №3-4. С.16-24. https://doi.org/ 10.31548/bio2019.03.002

Аннотаиия. Белая гниль георгины является опасной болезнъю, которая в Украине мало изученная. Для уточнения симптоматики болезни и влияния метеорологических условий на ее разви тие нами проведены исследования в течение 2015 - 2017 г2. на территории г. Киева. При изучении диагностических признаков заболевания применя ли визуальный осмотр и биологический метод диагностики. Развитие болезни оченивали по шестибальной шкале. В результате фитопатологического мониторинга вылялено стеблевую форму белой гнили. Сильное поражение растений приводило к махераиии тканей и надламыванию стеблей и иветоносов. Развитие болезни в прикорневой части стебля вызывало увяданий растений. За годы исследований белая гниль на георгине проявлялась в осенний период вегетаиии растений во время массового иветения. На ее распространение и развитие значительно влияли метеорологиче ские условия. В частности, в 2015 году склероти ниоз георгины проявлялся, начиная с первой дека дъ сентября при гидротермическом коэффииченте (ГТК) 1,0. В 2016 болезнь появлялась на растениях в первой декаде октлбря, когда ГТК составлал 5, 7. Первые растения, пораженные белой гнилью в 2017 г. нами отмеченъ во второй декаде сентлбрл при ГТК 1,2. Именно в этом году болезнь приобретала максимального распространения $и$ развития, что обусловлено наличием атмосферных осадков начиная со второй декады сентлбря и до кониа октлбря, а также отсутствием низких температур за этот период. Информачия о сроках появления белой гнили на георгине заслуживает внимания при планировании комплекса зашитных мероприятий. В дальнейшем глубокий анализ влияния различных метеорологических факторов на развитие белой гнили георгины челесообразно применять при составлении моделей прогноза развития болезни на этой культуре.

Ключевые слова: белая гниль, георгины, силптомы, метеорологические условия, развитие болезни 